\title{
Effects of reducing the remating interval after parturition on the fertility and plasma concentrations of luteinizing hormone, prolactin, oestradiol-17 $\beta$ and progesterone in lactating domestic rabbits
}

\author{
I. C. Lamb ${ }^{1, *}$, W. Strachan ${ }^{1}$, G. Henderson ${ }^{2}$, T. Atkinson ${ }^{1}$, W. Lawson ${ }^{1}$, \\ G. G. Partridge ${ }^{1, \dagger}$, M. F. Fuller ${ }^{1} \ddagger$ and P. A. Racey ${ }^{3}$ \\ ${ }^{1}$ Rowett Research Institute, Bucksburn, Aberdeen AB2 9SB, UK; ${ }^{2}$ Department of Agricultural \\ Biochemistry, University of Aberdeen, Aberdeen AB9 1AS,UK; and ${ }^{3}$ Department of Zoology, \\ University of Aberdeen, Aberdeen $A B 92 T N, U K$
}

\begin{abstract}
Summary. Primiparous crossbred does were remated on Day $1(n=15)$ or $14(n=25)$ post partum and killed on Day 10 post coitum to assess their fertility. Blood samples were taken during the pre- $(0-12 \mathrm{~h}$ post coitum $)$ and post- ( $1-10$ days post coitum $)$ ovulatory periods and plasma was assayed for luteinizing hormone (L.H), prolactin, oestradiol-17 $\beta$ and progesterone. Ovulation response was significantly greater $(P<0.01)$ and ovulation rate significantly lower $(P<0.001)$ in does mated on Day 1 than in those mated on Day 14 post partum. Does failing to ovulate on Day 14 post partum exhibited no preovulatory LH surge and had significantly lower $(P<0.05)$ premating concentrations of oestradiol- $17 \beta$ and prolactin than those ovulating at this time. No significant differences in hormone concentrations were observed during the preovulatory period between does ovulating on Days I and 14 post partum, with the exception of oestradiol-17 $\beta$. Concentrations of this hormone were significantly lower $(P<0.01)$ in does mated on Day 1 , at 1 h post coitum. We conclude that (i) fertility was affected by the remating interval after parturition, (ii) ovulation failure was associated with an absence of the preovulatory $\mathrm{LH}$ surge and a reduction in premating concentrations of oestradiol-17 $\beta$ and prolactin and (iii) the lower ovulation rate in early lactation was apparently caused by a reduction in ovarian competence to respond to the gonadotrophic stimulus.
\end{abstract}

Keywords: rabbit; remating; prolactin; oestradiol; progesterone

\section{Introduction}

Rabbits are able to establish pregnancy concurrent with lactation. Some authors have shown that fertility is lower in lactating does remated soon after parturition than in those remated later in lactation (ovulation response, Foxcroft \& Hasnain, 1973a; ovulation rate, Torrés et al., 1977; fertilization rate, Torrés et al., 1977; preimplantation embryo survival, Foxcroft \& Hasnain, 1973b; pregnancy rate, Prud'hon et al., 1969; litter size at term, Prud'hon et al., 1969; Surdeau et al., 1979). Others have reported no such reduction in these components of fertility (Prud'hon \& Bel, 1968; Harned \& Casida, 1969; Prud'hon et al., 1969; Foxcroft \& Hasnain, 1973a, b; Torrés et al., 1977; Partridge et al., 1984).

*Present address: WIL Research Laboratories Inc., Ashland, Ohio 44805, USA.

tPresent address: B.P. Nutrition (UK) Ltd, Wincham, Northwich, Cheshire CW9 6DF, UK

$\ddagger$ Reprint requests. 
Little is understood about the endocrine events underlying the reproductive physiology of lactating rabbits. Most evidence is of an indirect nature; changes in ovarian follicular development, regression of corpora albicantia and development of corpora lutea following ovulation have been described (Harned \& Casida, 1969; Breed \& Hilliard, 1970; Foxcroft \& Hasnain, 1973a; Torrés et al., 1977). Changes in ovarian steroid secretion and pituitary content of luteinizing hormone (LH) during lactation have also been reported (Breed \& Hilliard, 1970; Foxcroft, 1972). This information is, however, of limited value for identifying possible endocrine events which may have been responsible for causing the apparent variability in fertility referred to above.

The present experiment aimed to (i) obtain further information on the effects of reducing the remating interval after parturition on the fertility of lactating rabbits, particularly in the early postpartum period and (ii) monitor the endocrine events associated with the observed fertility by measuring plasma hormone concentrations. Groups of does were remated on the 1st or 14th day after parturition; the latter group served as a control treatment since fertility apparently becomes normal at this time (Prud'hon et al., 1969).

\section{Materials and Methods}

Experimental procedures. Primiparous crossbred does (New Zealand White $(\mathrm{NZW}) \times(\mathrm{NZW} \times$ Californian)) were allocated on the day of parturition (Day 0$)$ to be mated either on Day $1(n=15)$ or Day $14(n=25)$ post partum. All 40 does were killed on Day 10 post coitum and there were 10 does with implantations for each treatment. All does suckled litters of 6 kits. Does were housed individually in standard flat-deck cages described by Spreadbury (1975) and provided with a nest box which allowed continuous access to the litter. House temperature was maintained between 18 and $21^{\circ} \mathrm{C}$ and a cycle of $14 \mathrm{~h}$ light: $10 \mathrm{~h}$ dark was used (lights on 07:00 h GMT) (Partridge et al., 1984). All does had unrestricted access to a supply of water and a pelleted diet based on grassmeal, weatings, soyabean meal and ground oats which contained $12 \mathrm{MJ}$ digestible energy $/ \mathrm{kg}$ dry matter $(\mathrm{DM})$ and $154 \mathrm{~g}$ digestible crude protein $/ \mathrm{kg} \mathrm{DM}$.

Sexual behaviour. The mating response of does was established as described by Foxcroft \& Hasnain (1973a). All does were tested for mating between 08:00 and 08:30 h. Males (of proven fertility) used for testing were individually caged and distributed evenly throughout the building occupied by the experimental does.

Fertility. Two measures of fertility were used in this experiment: (i) the occurrence of ovulation after mating and (ii) the occurrence of implantation after ovulation. Does were killed by cervical dislocation and the reproductive tracts were removed for examination. When ovulation had occurred, corpora lutea vera (Halliday, 1959) were counted to establish the ovulation rate. The numbers of antimesometrial swellings in each uterine horn were counted to establish the implantation rate. If implantation had not occurred, the uterine horns were opened and the endometrium was examined under a dissecting microscope for sites of decidual reaction.

Blood sampling. To evaluate the pattern of endocrine changes associated with aspects of fertility, blood samples $(\sim 2 \mathrm{ml})$ were taken during the pre- and postovulatory periods. Blood was collected into heparinized tubes, following marginal ear venesection without anaesthesia, while the rabbits were held by an assistant. Preliminary experiments (I. C. Lamb, unpublished observations) showed that samples could be obtained quickly by this method and without causing a stress-induced release of prolactin. In the preovulatory period, samples were taken immediately before mating $(0 \mathrm{~h})$, every hour for $10 \mathrm{~h}$, and at $12 \mathrm{~h}$ after mating. All samples were assayed for $\mathrm{LH}$, oestradiol-17 3 and progesterone. Prolactin was assayed only in the samples taken at 0,6 , and $12 \mathrm{~h}$. In the postovulatory period, samples were taken $1,1 \cdot 5,2,3,4,5,6,7,8,9$, and 10 days after mating and all were assayed for all 4 hormones. Blood from all does was monitored for packed cell volume. No animal became anaemic during the experiment.

Hormone assays. Plasma concentrations of LH and prolactin were quantified using specific, homologous, doubleantibody radioimmunoassays based on kits (LH, Osteen \& Mills, 1979; Mills et al., 1981, 1983; Patritti-Laborde et al., 1984; prolactin, Fuchs et al., 1981; Muccioli et al., 1983). The intra- and interassay coefficients of variation (C.V.) for the LH assay were 5.9 and $7.1 \%$, respectively, and for the prolactin assay 5.1 and $8.3 \%$, respectively. The assay sensitivity, expressed as the value of 2 standard deviations below maximum binding (zero standard), was $0 \cdot 1 \mathrm{ng} \mathrm{LH} / \mathrm{ml}$ and $1 \mathrm{ng}$ prolactin $/ \mathrm{ml}$.

Plasma concentrations of progesterone and oestradiol-17 $\beta$ were quantified by radioimmunoassays described by Adam \& Atkinson (1984) and Varley et al. (1981), respectively. The intra- and interassay C.V. were 6 and $13 \%$, respectively, for the progesterone assay; and 13 and $9 \%$, respectively, for the oestradiol-17 $\beta$ assay. The assay sensitivity was $0 \cdot 3 \mathrm{ng}$ progesterone $/ \mathrm{ml}$ and $3 \mathrm{pg}$ oestradiol- $17 / \mathrm{\beta} / \mathrm{ml}$.

Statistical analysis. The effect of treatment on fertility was determined using $\chi^{2}$ tests and Student's $t$ tests. The hormonal data were analysed using analysis of variance followed by Duncan's New Multiple Range test. 


\section{Results}

\section{Fertility}

The ovulation response and ovulation rate were significantly greater $(P<0.01)$ and lower $(P<0.001)$, respectively, in does mated on Day 1 than on Day 14 post partum (Table 1$)$. There were no other significant effects of the remating interval after parturition on fertility.

Table 1. Fertility of does (number in parentheses) mated on Day 1 or Day 14 post partum

\begin{tabular}{|c|c|c|c|}
\hline & \multicolumn{2}{|c|}{ Day of mating post partum } & \multirow[b]{2}{*}{ Significance } \\
\hline & 1 & 14 & \\
\hline $\begin{array}{l}\text { No. of does } \\
\text { Mating response }(\%)^{*} \\
\text { Ovulation response }(\%) \dagger \\
\text { Ovulation rate (mean } \pm \text { s.e.m.) } \\
\text { Implantation response }(\%) \ddagger \\
\text { Implantation rate (mean } \pm \text { s.e.m.) } \\
\text { Preimplantation mortality }(\%) \S \\
\text { Preimplantation mortality }(\%) \subsetneq\end{array}$ & $\begin{array}{l}15 \\
100(15) \\
100(15) \\
9 \cdot 5 \pm 0 \cdot 6(15) \\
67(10 / 15) \\
8 \cdot 2 \pm 0 \cdot 9(10) \\
13 \\
43\end{array}$ & $\begin{array}{l}25 \\
88(22) \\
64(14 / 22) \\
14 \cdot 2 \pm 0 \cdot 7(14) \\
71(10 / 14) \\
9 \cdot 8 \pm 1 \cdot 6(10) \\
28 \\
51\end{array}$ & $\begin{array}{c}\text { N.S. } \\
P<0.01 \\
P<0.001 \\
\text { N.S. } \\
\text { N.S. } \\
\text { N.S. } \\
\quad-\end{array}$ \\
\hline $\begin{array}{l}\text { Percentage of does ovulating in re } \\
\text { Percentage of does ovulating havi } \\
\text { observed, exclusive of total loss } \\
\text { Inclusive of total loss of eggs/emb }\end{array}$ & $\begin{array}{l}\text { ted to the } m \\
\text { se to mating. } \\
\text { plantation } s \\
\text { tation as a } \\
\text { s/embryos b }\end{array}$ & $\begin{array}{l}\text { ntage of total } \\
\text { implantation. }\end{array}$ & ora lutea \\
\hline
\end{tabular}

\section{Hormones}

\section{Preovulatory period}

There was no effect of the remating interval after parturition on the temporal changes of the 4 hormones during the preovulatory period (Fig. 1), except that, at $1 \mathrm{~h}$ post coitum, the mean oestradiol-17 $\beta$ concentration was significantly $(P<0.01)$ greater in does ovulating on Day 14 $(20.4 \pm 1.4 \mathrm{pg} / \mathrm{ml})$ than on Day $1(15.4 \pm 1.4 \mathrm{pg} / \mathrm{ml})$ post partum.

Does which failed to mate on Day 14 post partum had a significantly $(P<0.025)$ lower premating mean concentration of oestradiol-17 $\beta$ than those ovulating at this time. There were no other significant differences in hormone concentrations between these two groups (Table 2). Does which did not ovulate after mating on Day 14 post partum showed no preovulatory LH surge (Fig. 1b) and had significantly lower $(P<0.05)$ premating mean concentrations of prolactin and oestradiol$17 \beta$ than does which did ovulate at this time. There were no other significant differences between these two groups in hormone concentrations before mating (Table 2). Mean concentrations of LH, progesterone and oestradiol-17 $\beta$ were significantly greater during the surge phase of the preovulatory period in does ovulating on Day 14 post partum than in those not ovulating at this time (see Fig. Ib for significance levels).

\section{Postovulatory period}

Within each treatment group (Days 1 and 14), there were no significant differences in the plasma concentrations of $\mathrm{LH}$, progesterone and prolactin between does that ovulated and subsequently did or did not have implantations. The data for these hormones were therefore combined within these respective groups (Fig. $2 a$ and b, (i), (ii) and (iii)). Plasma oestradiol-17 $\beta$ concentrations are presented separately within each treatment group for does that ovulated and subsequently had implants, or did not have implants (Fig. 2a and b, (iv)) because mean oestradiol-17 
(a)

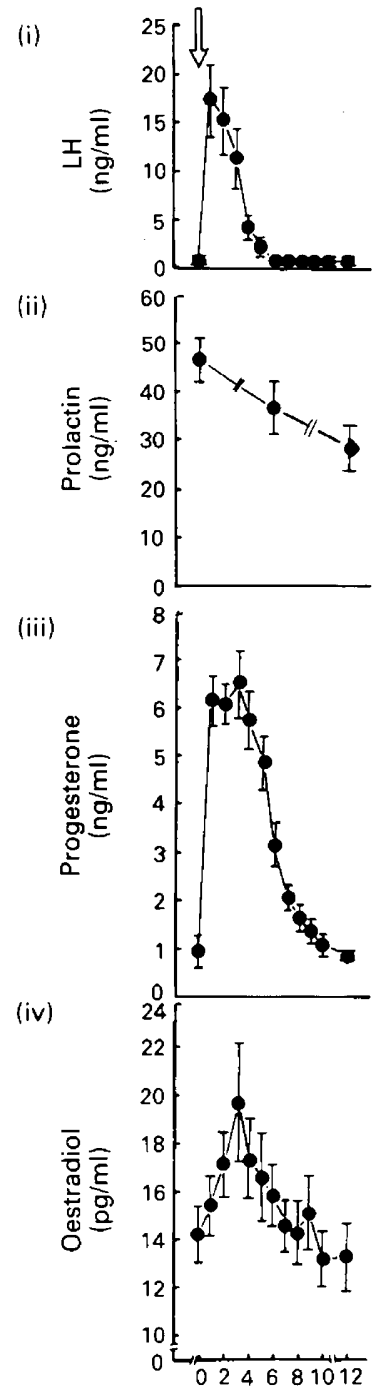

(b)
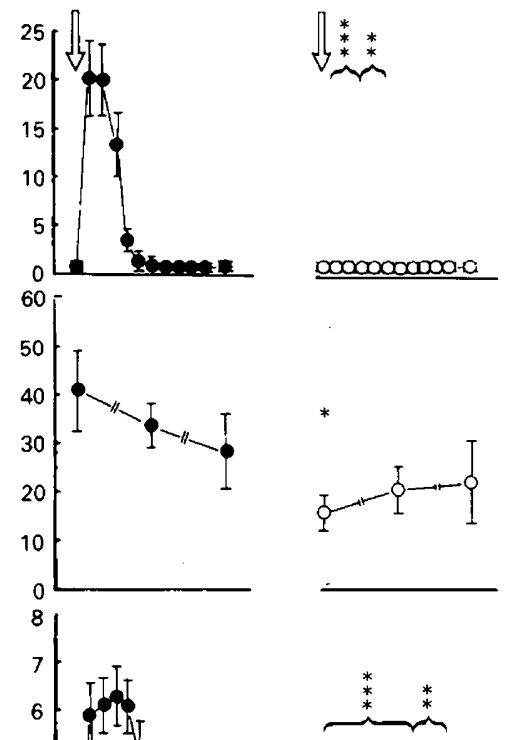

$9600000098-0$

$\stackrel{+}{* * *}$

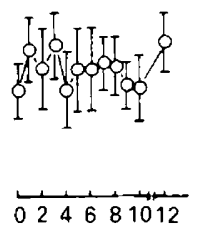

Time after mating (h)

Fig. 1. Changes in plasma concentrations of (i) luteinizing hormone (LH), (ii) prolactin, (iii) progesterone and (iv) oestradiol-17 $\beta$ during the preovulatory period in does mated on (a) Day 1 post partum $(n=15)$ and (b) Day 14 post partum; lactating rabbits which $(\bullet)$ ovulated $(n=14)$ or (O) failed to ovulate $(n=8)$. Significance symbols $\left({ }^{*} P<0.05,{ }_{*}^{+} P<0.025,{ }^{* *} P<0.01\right.$, $\left.{ }^{* * *} P<0.001\right)$ denote a difference at a particular time in hormone concentrations between does ovulating and those failing to ovulate on Day 14 post partum. Arrows denote the time of mating. Data are means \pm s.e.m.

concentrations were significantly $(P<0.05)$ greater $(15.1 \pm 1.5 \mathrm{vs} .9 .2 \pm 0.4 \mathrm{pg} / \mathrm{ml})$ and lower $(13.6 \pm 1 \cdot 2$ vs. $22.7 \pm 2 \cdot 1 \mathrm{pg} / \mathrm{ml})$ in does with implantations than in those with no implantations on Days 4 and 3 after mating for the Day 1 and 14 post-partum treatment groups, respectively.

There was no effect of the remating interval after parturition on the mean concentrations of $\mathrm{LH}$, prolactin and oestradiol-17 $\beta$ during the postovulatory period. Mean concentrations of progesterone were, however, significantly greater in does ovulating on Day 14 post partum and on Days 6 
Table 2. Premating plasma hormone concentrations in does on Day 14 post partum, which subsequently ovulated, failed to ovulate or failed to mate

\begin{tabular}{|c|c|c|c|c|}
\hline Hormone & Ovulating & Not ovulating & Not mating & Significance \\
\hline Oestradiol-17ß (pg/ml) & $16 \cdot 7 \pm 0 \cdot 8^{\mathrm{a}}$ & $13 \cdot 3 \pm 1 \cdot 3^{b}$ & $11 \cdot 4 \pm 2 \cdot 1^{\mathrm{c}}$ & $\begin{array}{c}P<0.05^{\text {ab }} \\
P<0.025^{\text {ac }} \\
\text { N.S. } \text {. }^{\text {c }}\end{array}$ \\
\hline Progesterone $(\mathrm{ng} / \mathrm{ml})$ & $0.39 \pm 0.2$ & $0.42 \pm 0.1$ & $0 \cdot 35 \pm 0 \cdot 7$ & N.S. \\
\hline Luteinizing hormone $(\mathrm{ng} / \mathrm{ml})$ & $0.51 \pm 0.08^{a}$ & $0.35 \pm 0.06^{\mathrm{b}}$ & $0.38 \pm 0.03$ & $P<0.10>P 0.05^{\mathrm{ab}}$ \\
\hline Prolactin $(\mathrm{ng} / \mathrm{mi})$ & $41 \cdot 6 \pm 8 \cdot 4^{a}$ & $15 \cdot 5 \pm 3 \cdot 3^{\mathrm{b}}$ & $16 \cdot 3 \pm 9.2$ & $P<0.05^{\mathrm{ab}}$ \\
\hline
\end{tabular}

Data are means \pm s.e.m.

Means with different superscripts are significantly different at the level indicated.

$(P<0.01), 8(P<0.025), 9(P<0.05)$, and $10(P<0.001)$ after mating than in does ovulating on Day 1 post partum.

Does failing to ovulate after mating on Day 14 post partum had significantly $(P<0.001)$ lower mean concentrations of progesterone than those ovulating at this time, on Days 3-10 after mating, because of the absence of corpora lutea. There were no other significant differences in hormone concentrations between these two groups.

\section{Discussion}

The present experiment confirms previous findings (Partridge et al., 1984; Lamb et al., 1988) that the fertility of rabbits is high during lactation, particularly in the period shortly after parturition. Of the fertility parameters recorded, only ovulation response and ovulation rate were significantly affected by the remating interval after parturition.

The reduction in the ovulation response of does after mating on Day 14 post partum contrasts sharply with a previous report which shows doe ovulation response to be higher than, or similar to, values observed in does mated in the early post-partum period (Foxcroft \& Hasnain, 1973a). This finding may relate to the use of rabbits of a different genotype and parity between studies (Foxcroft \& Hasnain, 1973a; Partridge et al., 1984).

Anovulation was associated with failure of the preovulatory LH surge (Harper, 1961) and significantly lower premating concentrations of oestradiol-17 $\beta$ and prolactin. Oestradiol-17 $\beta$ acts at the hypothalamic (Sawyer \& Markee, 1959) and pituitary (Sawyer \& Markee, 1959; Dufy-Barbe et al., 1975) level in rabbits to facilitate ovulation; reduced concentrations of this steroid before mating may have rendered either or both sites refractory to the coital stimulus. The ovarian follicle is the main source of oestradiol-17ß, secretion of which is LH-dependent (Mills et al., 1971). Since ovarian function is not directly affected by lactation or suckling (Breed \& Hilliard, 1970), it is likely that a reduction in $\mathrm{LH}$ was responsible for the reduction in oestradiol-17 $\beta$ before mating. To corroborate such a suggestion, there was some evidence of a lower premating basal concentration of LH in does failing to ovulate, but this just failed to reach significance (see Table 2).

Suckling normally occurs once a day in rabbits (Zarrow et al., 1965) and the secretion of prolactin is dependent on the sucking stimulus of the litter (Fuchs et al., 1984). Premating concentrations of prolactin in does ovulating on Day 14 post partum were similar to those found by Fuchs et al. (1984) following suckling, while those in does failing to ovulate were significantly lower, despite an apparent equal suckling stimulus between groups, i.e. litter size and weight (data not shown) were similar, and that all litters were observed to have fed (i.e. all had distended stomachs) before the blood sampling period. This observation may be spurious and simply reflect an inherently lower secretion of prolactin in response to suckling and/or an earlier or shorter suckling period in the group of does failing to ovulate. The similarity, however, in the premating hormone concentrations between does ovulating on Days 1 and 14 post partum, and those failing to ovulate 
(a)

(i)

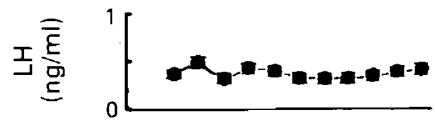

(ii)

(iii)
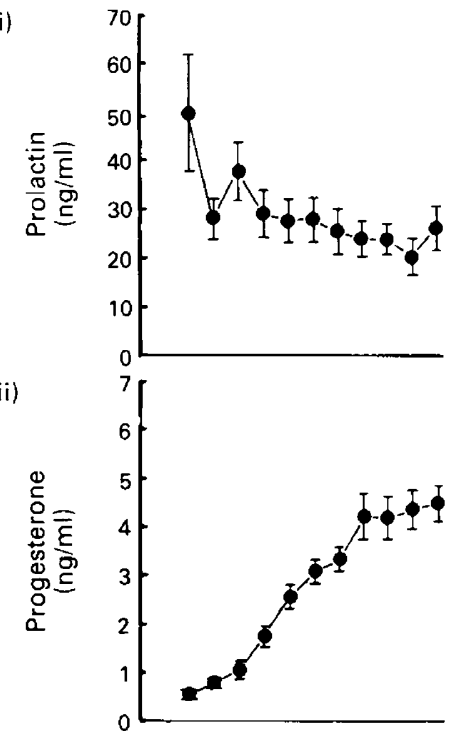

(iv)

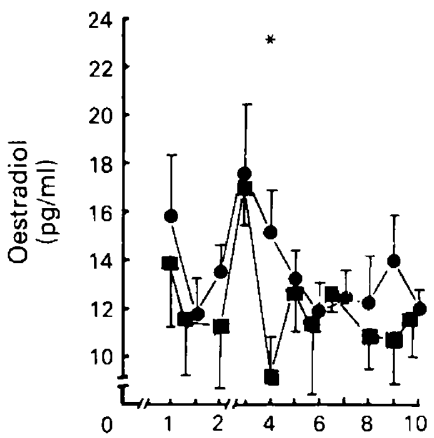

(b)
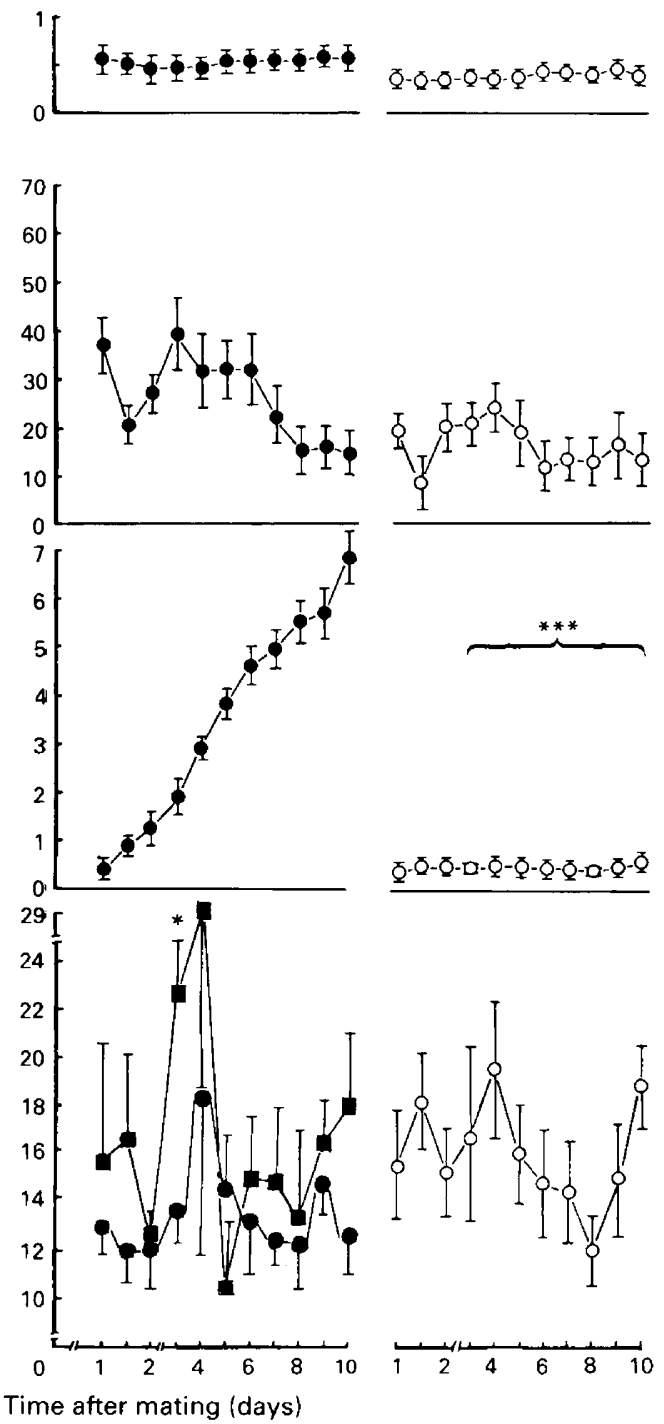

Fig. 2. Changes in plasma concentrations of (i) luteinizing hormone (LH), (ii) prolactin, (iii) progesterone and (iv) oestradiol-17 $\beta$ during the postovulatory period in does mated on (a) Day 1 post partum, $n=10(\bullet)$ and $5(\boldsymbol{\square})$ and (b) Day 14 post partum, $n=10(\bullet), 8(\bigcirc)$ and $4(\boldsymbol{\square})$; lactating does with $(\bullet)$ or without $(\boldsymbol{\square})$ implantation sites; $(O)$ does failing to ovulate. $P<0.05$ significance symbol $\left({ }^{*}\right)$ indicates a significant difference in oestradiol-17 $\beta$ concentration between does with and without implantation sites at Day 1 or Day 14 post partum; ${ }^{* * *} P<0.001$ indicates a significant difference in progesterone concentration between does ovulating and those not ovulating on Day 14 post partum.

and mate on Day 14 post partum (see Fig. 1a, b and Table 2), suggests that an abnormal pattern of prolactin release may have occurred. Suckling has been shown to depress ovulation response in rabbits (Harned \& Casida, 1969; Foxcroft \& Hasnain, 1973a). In other species, the release of prolactin during lactation and suckling is accompanied by a reduction in gonadotrophin secretion and ovarian activity (McNeilly, 1987). It remains to be determined whether prolactin in involved in causing the reduction in oestradiol $-17 \beta$ and ovulation in lactating rabbits. 
The lower ovulation rate observed in early lactation confirms previous findings that the ovulation rate increases as the remating interval is extended post partum (Torrés et al., 1977). The temporal changes in plasma $\mathrm{LH}$, progesterone and oestradiol-17 $\beta$ during the preovulatory period of does ovulating on Days 1 and 14 post partum were similar to those reported for oestrous rabbits following coitus ( $\mathrm{LH}$, Osteen \& Mills, 1979; progesterone and oestradiol-17 $\beta$, Waterston \& Mills, 1976; Kumari \& Das, 1977; Wu et al., 1977), while concentrations of prolactin were similar to those in lactating does following suckling (Fuchs et al., 1984). The significant reduction in oestradiol-17 concentrations $1 \mathrm{~h}$ after mating in does ovulating on Day 1 post partum suggests that the reduction in ovulation rate may have resulted from reduced ovarian competence to respond to the preovulatory LH surge and that this resides in the follicles which represent the only gonadal source of this steroid (Mills et al., 1971). Further studies are required to resolve whether this apparent reduction in ovarian competence reflects a reduction in initial ovarian follicular development and/ or responsiveness to the LH surge at this time post partum. Either situation would probably influence subsequent preovulatory oestradiol-17 $\beta$ secretion and hence preovulatory follicular growth (Weilgosz et al., 1980) and ovulation rate.

Preimplantation mortality was unaffected by the time of mating post partum and the concentrations observed were similar to those found previously (Harned \& Casida, 1969; Foxcroft \& Hasnain, 1973b; Torrés et al., 1977). The present results also confirm previous findings (Foxcroft \& Hasnain, 1973b; Torrés et al., 1977) that the reproductive tract is capable of supporting sperm transport, capacitation, fertilization, ovum transport and implantation soon after parturition (in $69 \%$ of does overall in the present experiment). Those individuals exhibiting a total loss of ova following ovulation on Days 1 and 14 post partum had significantly higher and lower concentrations of oestradiol- $17 \beta$ on Days 4 and 3 after mating, respectively, than their implanting counterparts. Whether or not this indicates a causative role for oestradiol-17 $\beta$ requires further examination; the alterations in this steroid in the 2 experimental groups were on different days after mating and in opposite directions. Oestradiol- $17 \beta$ is known to affect ovum transport (Harper, 1966; Hodgson et al., 1980), oviducal fluid secretion (Mastroianni et al., 1961), mucin synthesis (Greenwald, 1958) and uteroglobin production (Rahman et al., 1975). Since decidual reactions were not observed in any doe without implantation sites and the alterations in oestradiol-17 $\beta$ values coincided with the time of ovum transport or entry into the uterus, and their transformation from the blastocyst to morula stage ( $\mathrm{Hafez}, 1970)$, these processes may have been altered by changes in oestradiol-17 $\beta$ and caused the total loss of eggs or embryos before implantation.

The higher concentrations of progesterone observed during the postovulatory period in does ovulating on Day 14 post partum may have been related to the higher ovulation rate in this group. The corpus luteum represents the only source of progesterone during gestation in rabbits (Thau \& Lanman, 1976), although Polidoro \& Black (1970) could not show a correlation between numbers of $\mathrm{CL}$ in the ovary and progesterone secretion. The animals in the present experiment were, however, also lactating and consequently the findings of Polidoro \& Black (1970) may not be applicable. Alternatively, the stage of lactation may alter the metabolic turnover rate of progesterone and thereby influence peripheral concentrations. Concentrations of $\mathbf{L H}$, oestradiol-17 $\beta$ and prolactin were similar between treatment groups during the postovulatory period, suggesting that, at least at the peripheral level, the luteotrophic support provided by these hormones was similar between treatments. Despite lower concentrations of progesterone in does ovulating on Day 1 post partum, this did not lead to increased incidence of preimplantation mortality. This indicates that luteal support of gestation was adequate up to the completion of implantation.

We thank Dr A. F. Parlow, NIAMDD Rat Pituitary Hormone Distribution Programme, University of California, Torrance, California, USA, for providing the rabbit LH and prolactin radioimmunoassay kits; the Scottish Antibody Production Unit for providing sera used in the radioimmunoassays; and Miss $\mathrm{M}$. Findlay and Mrs W. Buchan for routine care of the experimental 
animals. I. C. Lamb was in receipt of an S.E.R.C. postgraduate studentship during the course of this work.

\section{References}

Adam, C.L. \& Atkinson, T. (1984) Effect of feeding melatonin to red deer (Cervus elaphus) on the onset of the breeding season. J. Reprod. Fert. 72, 463-466.

Breed, W.G. \& Hilliard, J. (1970) Effect of lactation on ovarian function in the rabbit. J. Reprod. Fert. 23, 7378.

Dufy-Barbe, L., Franchimont, P., Dufy, B. \& Vincent, J.D. (1975) Effects of ovariectomy and oestradiol benzoate treatment on $\mathrm{LH}-\mathrm{RH}$ induced $\mathrm{LH}$ and $\mathrm{FSH}$ release in the female rabbit. Horm. Res. 6, 372-379.

Foxcroft, G.R. (1972) Reproductive physiology of the post parturient domestic rabbit. $\mathrm{Ph} . \mathrm{D}$. thesis, University of Nottinhgam.

Foxcroft, G.R. \& Hasnain, H. (1973a) Effects of suckling and time to mating after parturition on reproduction in the domestic rabbit. J. Reprod. Fert. 33, 367377.

Foxcroft, G.R. \& Hasnain, H. (1973b) Embryonic mortality in the post-parturient domestic rabbit. $J$. Reprod. Fert. 33, 315-318.

Fuchs, A-R., Cubile, L. \& Dawood, M.Y. (1981) Effects of mating on levels of oxytocin and prolactin in the plasma of male and female rabbits. J. Endocr. 90, 245-253.

Fuchs, A-R,, Cubile, L., Dawood, M.Y. \& Jorgensen, F.S. (1984) Release of oxytocin and prolactin by suckling in rabbits throughout lactation. Endocrinology 114, 462.569 .

Greenwald, G.S. (1958) Endocrine regulation of the secretion of mucin in the tubal epithelium of the rabbit. Anat. Rec. 130, 477-496.

Hafez, E.S.E. (1970) Female reproductive organs. In Breeding Techniques for Laboratory Animals, pp. 74 106. Ed. E. S. E. Hafez. Lea \& Febiger, Philadelphia.

Halliday, R. (1959) The occurrence of corpora lutea atretica in the ovaries of pregnant domestic rabbits. J. Endocr. 19, 10-15.

Harned, M.A. \& Casida, L.E. (1969) Some post partum reproductive phenomena in the domestic rabbit. $J$. Anim. Sci. 28, 785-788.

Harper, M.J.K. (1961) The time of ovulation in the rabbit following the injection of luteinizing hormone. J. Endocr. 22, 147-152.

Harper, M.J.K. (1966) Hormonal control of transport in eggs in cumulus through the ampulla of the rabbit oviduct. Endocrinology 78, 568-574.

Hodgson, B.J., Nork, T.M., Heesch, C.M. \& Johns, A. (1980) Effect of ovulation and oestrogen and progesterone on mechanical properties of smooth muscle of rabbit oviduct. Biol. Reprod. 22, 1160-1167.

Kumari, G.L. \& Das, C. (1977) Pre and post-ovulatory changes in the levels of steroid hormones of rabbit ovary on in-vivo administration of LH. J. Steroid. Biochem. 8, 1097-1103.

Lamb, I.C., Partridge, G.G., Fuller, M.F. \& Racey, P.A. (1988) Fertility of the early post partum lactating domestic rabbit. Theriogenology 30, 75-82.

Mastroianni, L., Beer, F., Shah, U. \& Clewe, T.H. (1961) Endocrine regulation of oviduct secretions in the rabbit. Endocrinology 68, 92-100.
McNeilly, A.S. (1987) Prolactin and the control of gonadotrophin secretion. J. Endocr. 115, 1-5.

Mills, T., Copland, J.A. \& Osteen, K. (1981) Factors affecting the post-ovulatory surge of FSH in the rabbit. Biol. Reprod. 25, 530-535.

Mills, T.M., Copland, J.A., Coy, D.H. \& Schally, A.V. (1983) Is the post-ovulatory release of folliclestimulating hormone in the rabbit mediated by luteinizing hormone-releasing hormone? Endocrinology 113, 1020-1024.

Mills, T.M., Davies, P.J.A. \& Savard, K. (1971) Stimulation of estrogen synthesis in rabbit follicles by luteinizing hormone. Endocrinology 88, 857-862.

Muccioli, G., Lando, D., Bellussi, G. \& DiCarlo, R. (1983) Physiological and pharmacological variations in rabbit prolactin plasma levels. Life Sci. 32, 703-710.

Osteen, K.G. \& Mills, T.M. (1979) Serum LH and FSH levels in the pregnant rabbit. Proc. Soc. exp. Biol. Med. 162, $454-457$.

Partridge, G.G., Allan, S.J., Findlay, M. \& Corrigall, W. (1984) The effects of reducing the remating interval after parturition on the reproductive performance of the commercial doe rabbit. Anim. Prod. 39, 465-472.

Patritti-Laborde, N., Rettori, V. \& Asch, R.H. (1984) The effects of porcine follicular fluid in the post-castration rise of gonadotrophins in the rabbit. Life Sci. 34, $555-560$.

Polidoro, J.P. \& Black, D.L. (1970) Peripheral plasma progesterone and the number of foetuses in normal and superovulated rabbits. J. Reprod. Fert. 22, 493-498.

Prud'hon, M. \& Bel, L. (1968) Le sevrage precoce des lapereaux et la reproduction des lapines. Annls Zootech. 17, 23-30.

Prud'hon, M., Rouvier, R., Cael, J. \& Bel, L. (1969) Influence de l'intervalle entre la parturition et la saillie dur la fertilite et la prolificite des lapins. Annls Zootech. 18, 317-329.

Rahman, S.S., Billiar, R.B. \& Little, B. (1975) Induction of uteroglobin in rabbits by progestagens, estradiol$17 \beta$ and ACTH. Biol. Reprod. 12, 305-314.

Sawyer, C.H. \& Markee, J.E. (1959) Estrogen facilitation of release of pituitary ovulating hormone in the rabbit in response to vaginal stimulation. Endocrinology 65, 614-621.

Spreadbury, D. (1975) Nutrient requirements of the growing rabbit. Ph.D. thesis, University of Aberdeen.

Surdeau, P., Perrier, G. Sartorio, J.M. \& Valentin, D. (1979) Comparison of two reproductive rhythms in the meat rabbit. First results. Annls Zootech. 28, 136, abstr.

Thau, R.B. \& Lanman, T. (1976) Metabolic clearance rates (MCR) and production rates (PR) of plasma progesterone in pregnant and pseudopregnant rabbits. Endocrinology $97,454-457$.

Torrés, S., Gerard, M. \& Thibault, C. (1977) Fertility factors in lactating rabbits mated 24 hours and 25 days after parturition. Annls Biol. anim. Biochim. Biophys. 17, 63-69. 
Varley, M.A., Atkinson,T. \& Ross, L.N. (1981) The effect of lactation length on the circulating concentrations of progesterone and oestradiol in the early weaned sow. Theriogenology 16, 179-184.

Waterston, J.W. \& Mills, T.M. (1976) Peripheral blood steroid concentrations in the preovulatory rabbit. $J$. Steroid Biochem. 7, 15 17.

Weilgosz, G.J., Low, M.J. \& Younglai, E.V. (1980) Effects of immunizing rabbits against oestradiol-6-
oxime-BSA on ovarian follicular development. Acta endocr., Copenh. 94, 235-241.

Wu, C.H., Blasco, L., Flickinger, G.L. \& Mikhail, G. (1977) Ovarian function in the preovulatory rabbit. Biol. Reprod. 17, $304-308$.

Zarrow, M.X., Denenberg, V.H. \& Anderson, C.O. (1965) Rabbit: frequency of suckling in the pup. Science, N.Y. 150, $1835-1836$.

Received 14 February 1991 